\title{
Study of Nanoskin ECM-Bacterial Cellulose Wound Healing/United Arab Emirates
}

\author{
Saqer Al Mualla1, Raed Farahat', Pierre Basmaji2, Gabriel Molina de Olyveira ${ }^{3 *}$, \\ Ligia Maria Manzine Costa ${ }^{4}$, José Domingos da Costa Oliveira², Gino Bruno Francozo² \\ ${ }^{1}$ Al Qassimi Hospital/Kuwait Hospital, Sharjah, United Arab Emirates \\ ${ }^{2}$ Innovatec's-Biotechnology Research and Development, São Carlos, Brazil \\ ${ }^{3}$ Department of Physical Chemistry, Universidade Estadual Paulista (UNESP), Araraquara, Brazil \\ ${ }^{4}$ Materials Engineering Department, São Carlos School of Engineering, University of São Paulo, São Carlos, Brazil \\ Email: "gabriel.ufabc@gmail.com, "gmolyveira@yahoo.com.br
}

Received 11 March 2016; accepted 26 April 2016; published 29 April 2016

Copyright (C) 2016 by authors and Scientific Research Publishing Inc.

This work is licensed under the Creative Commons Attribution International License (CC BY).

http://creativecommons.org/licenses/by/4.0/

(c) (i) Open Access

\begin{abstract}
Natural extracellular matrices (ECMs) perform the tasks necessary for tissue formation, maintenance, regulation and function, providing a powerful means of controlling the biological performance of regenerative materials. In addition, biomedical materials have claimed attention because of the increased interest in tissue engineering materials for wound care and regenerative medicine. Moreover, the nanostructure and morphological similarities with collagen make BC attractive for cell immobilization, cell support and Natural Extracellular Matrix (ECM) Scaffolds. In this work, we present the extracellular matrix (ECM) using the bacterial cellulose (Nanoskin ${ }^{\circledR}$ ) which regulates cell behavior by influencing cell proliferation, survival, shape, migration and differentiation. Bacterial cellulose fermentation process is modified before the bacteria are inoculated for mimicking ECM to cells support and built new local material for wound healing. Chemical groups influences and thermal behavior in bacterial cellulose were analyzed using transmission infrared spectroscopy (FTIR) and thermogravimetric analysis (TGA), respectively. Besides, In vivo analysis was evaluated with clinical study at Sharjah Kuwait Hospital.
\end{abstract}

\section{Keywords}

Bacterial Cellulose (Nanoskin), Natural Nanocomposites, Regenerative Medicine, Stem Cells

\section{Introduction}

Tissue engineering is a recent field that creates functioning artificial tissues and organs. Major considerations in ${ }^{*}$ Corresponding author.

How to cite this paper: Al Mualla, S., Farahat, R., Basmaji, P., de Olyveira, G.M., Costa, L.M.M., da Costa Oliveira, J.D. and Francozo, G.B. (2016) Study of Nanoskin ECM-Bacterial Cellulose Wound Healing/United Arab Emirates. Journal of Biomaterials and Nanobiotechnology, 7, 109-117. http://dx.doi.org/10.4236/jbnb.2016.72012 
tissue engineering include both the type of cell and the substrate (scaffold) to be used. Many strategies use an artificial scaffold that functions as the ECM to facilitate both organization and differentiation of implanted cells into a functional 3D tissue [1].

Wounds are injuries that result in an ulcer or break of the skin. Healing is a complex process in response to an injury to restores the integrity of wound. Wound healing involves cell-cell and cell matrix interactions to allow the process [2] [3]. Besides, wounds are followed by inflammatory processes with various mediators, such as eicosanoids, prostaglandins or cytokines [4]. NF-B is one central protein that regulates several inflammatory cytokines with IB, its inhibitory subunit. However, there are many factors which help NF-B activity break IB linkage. Because of this, to avoid inflammatory action, inhibition of NF-B activation is crucial to treat wounds inflammation [4].

The extracellular matrix (ECM) contains an abundant variety of signals that are received by cell surface receptors and contribute to cell adhesion and cell fate, via regulation of cellular activities such as proliferation, migration and differentiation. As such, regenerative medicine studies often rely on mimicking the natural ECM to promote the formation of new tissue by host cells, and characterization of natural ECM components is vital for the development of new biomimetic approaches [5] [6].

The failure of re-ephitelialization in a poorly wound healing is initially due a deficit in the epithelial cell itself, typically in slow to heal wounds like diabetic ulcers, however, lack of normal ECM is now recognized to be the problem as fibronectin and collagen are required for the cells to attach to the surface and migrate [7]-[11].

In this scope, Natural ECM is the ideal biological scaffold since it contains all the components of the tissue. Constructive remodeling can be performed using such natural ECM scaffolds and vegetal/animal stem cells since, the cells can be delivered to the site of infraction and then cells help wound healing process. The development of niche mimicking biomaterials and hybrid biomaterial can further advance directed differentiation without specific induction [12] [13].

Bacterial cellulose (BC) is a natural cellulose produced by bacterial synthesis by biochemical steps and selfassembling of the secreted cellulose fibrils on the medium [14] [15]. Shaping of BC materials in the culture medium can be controlled by the type of cultivation that changes chain size, origin of strains which produces different proportions of crystalline phase of BC and the kind of bioreactor. BC hydrogel or BC in dry state is then obtained by methods, such as freeze-drying [16] [17]. The structural features of microbial cellulose, its properties and compatibility as a biomaterial for regenerative medicine can be changed by modifying its culture medium [18] or surface modification by physical [19] [20]; chemical methods [21] and genetic modifications [22] to obtain a biomaterial with less rejection when in contact to the body [23] [24].

In this work, novel studies of natural nanocomposites with Bacterial cellulose (Nanoskin ${ }^{\circledR}$ ) for functional materials are reported. In order to produce scaffolds with drug delivery ability, porous structure and better cell adhesion, fermentation changes in gel bacterial cellulose with chondroitin 4-sulfate, hyaluronic acid and vegetal stem cells were performed with its in vivo cell behavior.

\section{Materials and Methods}

\subsection{Materials}

The Bacterial cellulose (Nanoskin ${ }^{\circledR}$ ) raw material was provided from Innovatec’s (São Carlos SP, Brazil). Chondroitin 4-sulfate and hyaluronic acid sodium salt from Streptococcus equi (bacterial glycosaminoglycan polysaccharide) were purchased from Sigma Aldrich. Vegetal stem cells were obtained from Brazillian environment, Waltheria Douradinha.

\subsection{Methods}

2.2.1. Synthesis of Bacterial Cellulose and Bacterial Cellulose/Chondroitin Sulfate/Hyaluronic Acid Bacterial cellulose (BC) is produced by Gram-negative bacteria Gluconacetobacter xylinus, which can be obtained consisting of an ultra fine network of cellulose nanofibers [19]. BC hydrogel or BC in dry state is then obtained by freeze-drying. The acetic fermentation process is achieved by using glucose as a carbohydrate source. Results of this process are vinegar and a nanobiocellulose biomass. The modified process is based on the addition of chondroitin 4-sulfate $(1 \% \mathrm{w} / \mathrm{w})$ and hyaluronic acid $(1 \% \mathrm{w} / \mathrm{w})$ to the culture medium (green tea) before the bacteria are inoculated. 


\subsubsection{Bionanocomposite Preparation}

In the present study, a novel biomaterial has been explored and different bacterial cellulose nanocomposites have been prepared; BC/chondroitin 4-sulfate/hyaluronic acid. Samples were washed and it's medium was changed with cells culture medium as illustrated in Figure 1.

\subsection{Vegetal Stem Cells}

The material of the plant of interest is collected and induced damage to causing the formation of scar tissue called callus. This tissue consists of totipotent cells, undifferentiated (stem cells) are collected and grown on agar plates to complete differentiation and generation of a homogeneous culture (2 - 10 days).

Cultures of these stem cells are grown in bioreactors and the batch is collected after all the sugar was metabolized. The cells are washed and homogenized to release secondary metabolites. Soluble metabolites in oil and water are collected and, if you need the isomalt-based spraying is performed.

\subsection{Characterization}

Transmission infrared spectroscopy (FTIR, Perkin Elmer Spectrum 1000)-Influences of hyaluronic acid (HA) and chondroitin 4-sulfate (CS) in bacterial cellulose were analyzed in the range between 250 and $4000 \mathrm{~cm}^{-1}$ and with $2 \mathrm{~cm}^{-1}$ resolution with samples.

Thermogravimetric analysis (TGA) was carried out for biocomposites using a NETZSCH TG 209F1 in oxygen environment, with a heating rate of $10 \mathrm{C} / \mathrm{min}$. The temperature range scanned was from 25 celsius degree to 650 celsius degree. The weight of all specimens was maintained around $10 \mathrm{mg}$.

In vivo analysis-Evaluation-Clinical study at Sharjah Kuwait Hospital under supervision of Dr. Saqer Al Mualla and Dr. Raed Farahat. Evaluation model-Crushed injury with amputation of the index, Middle and ring of the right hand during work with skin loss since 5 days and all wounds shows necrotic tissue with black parts, bad offensive odor and small amount of pus.

\section{Results and Discussion}

\subsection{FTIR-Interaction between Bacterial Cellulose with Hyaluronic Acid and Chondroitin 4-Sulfate}

Influences of chondroitin 4-sulfate (CS) and hyaluronic acid in bacterial cellulose (BC) were analyzed by ATRFTIR in the range of $4000-2400 \mathrm{~cm}^{-1}$ (Figure 2) with resolution of $2 \mathrm{~cm}^{-1}$. The main features of the bacterial cellulose in mid-infrared spectroscopy are at $3349 \mathrm{~cm}^{-1}$ (sharp band; O-H stretching vibration associated to intramolecular hydrogen bonding), $3240 \mathrm{~cm}^{-1}$ (medium band; OH Stretching characteristic of hydroxyl



Figure 1. Materials and methods draft. 


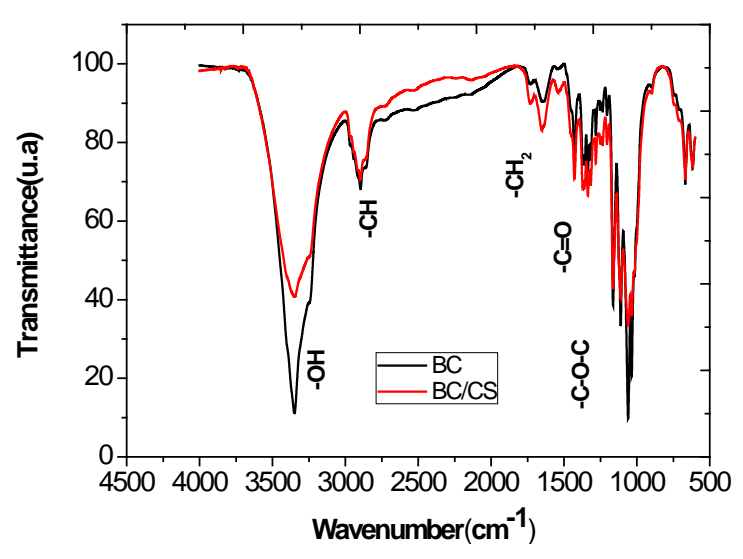

(a)

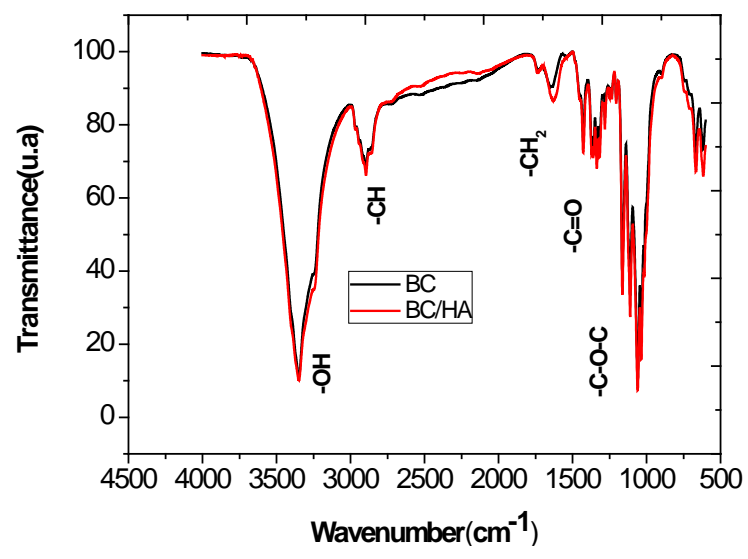

(b)

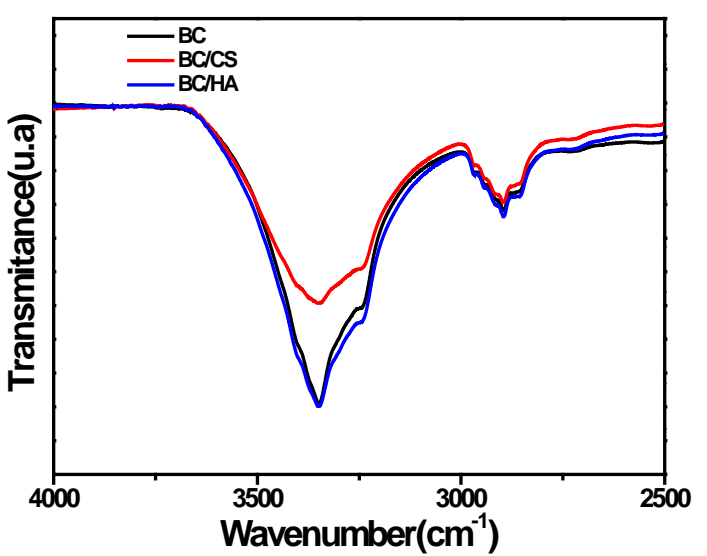

(c)

Figure 2. FTIR spectra of bacterial cellulose nanocomposites.

bonding in cellulose structure due to I $\alpha$ crystalline phase), $2896 \mathrm{~cm}^{-1}$ (C-H stretching vibration of alkane and asymmetric $\mathrm{CH}_{2}$ stretching), $2853 \mathrm{~cm}^{-1}\left(\mathrm{CH}_{2}\right.$ symmetric stretching), $1732 \mathrm{~cm}^{-1}$ (stretching vibration of saturated aliphatic aldehyde carbonyl of BC), $1640 \mathrm{~cm}^{-1}$ (bending mode of absorbed water), $1428 \mathrm{~cm}^{-1}\left(\mathrm{CH}_{2}\right.$ or O-H in plane bending), $1373 \mathrm{~cm}^{-1}$ (C-H bending), $1340 \mathrm{~cm}^{-1}$ (OH in-plane bending), $1237 \mathrm{~cm}^{-1}$ (O-H bending), 1203 $\mathrm{cm}^{-1}$ (C-O-H in plane bending at C-6), $1163 \mathrm{~cm}^{-1}$ (strong band; antisymmetric bridge C-O-C strentching), 1110 $\mathrm{cm}^{-1}$ (strong band; antisymmetric in-phase ring stretching), $1065 \mathrm{~cm}^{-1}$ (strong band; skeletal vibrations involving C-O stretching at C-3), $1035 \mathrm{~cm}^{-1}$ (strong band; skeletal vibrations involving C-O stretching at C-6), 1015 $\mathrm{cm}^{-1}$ (medium band; skeletal vibrations involving C-O stretching), $897 \mathrm{~cm}^{-1}$ ( $\beta$-glucosidic linkages between the glucose units) and $748 \mathrm{~cm}^{-1}$ (OH stretching characteristic of hydroxyl bonding in cellulose structure due to $\mathrm{I} \alpha$ crystalline phase) [23]-[26].

It can be observed from Figures 2(a)-(c), the transmittance intensity is different of bacterial cellulose and bacterial cellulose nanocomposites, which means the exposed groups are interacting with bacterial cellulose components. Similar OH stretching (at $2900 \mathrm{~cm}^{-1}$ ) can be observed in bacterial cellulose/hyaluronic nanocomposites (BC/HA) and chondroitin 4-sulfate nanocomposites (BC/CS), mainly because of the $\mathrm{NH}_{2}$ interaction with hydroxyl groups (Figures 2(a)-(c)). Besides, changes can be observed in the symmetrical stretching of $\mathrm{CH}_{2}$ bonds of bacterial cellulose structures at the absorption peak of $1640 \mathrm{~cm}^{-1}$. Another absorption peak was obtained in the range of $1490 \mathrm{~cm}^{-1}$ on both samples, which shows the presence of a carbonyl group in the bacterial cellulose together with bonds corresponding to those of glycoside, including C-O-C at $1162 \mathrm{~cm}^{-1}$ (as in the case of natural cellulose) [23]-[26]. These results clearly show one possible interaction between bacterial cellulose and chondroitin 4-sulfate/hyaluronic acid, mainly by hydrogen interactions between hydroxyl and carbonyl groups. 


\subsection{TGA}

In order to analyze thermal behavior for bionanocomposites are characterized typical weight loss versus temperature plots. The TG spectrum (Figure 3) shows a weak loss of weight due to the evaporation of water (at temp. 85 celsius) and also quick drop in weight at a temperature of approx. 300 celsius is mainly attributed to thermal depolymerization of cellulose and the cleavage of glycosidic linkages of cellulose [27] [28], complete degradation of cellulose take place between 275 and 400 celsius [29] [30].

All system has similar thermal behavior in bacterial cellulose showed significant alterations. A carbonaceous residue was similar in BC membranes, around $0 \%$ at 600 celsius, however sample with hyaluronic acid has little differences in thermal behavior than tested others mainly because there is higher hydrogen bond between bacterial cellulose groups (hydroxyl) and hyaluronic acid (acetyl) which changes bacterial cellulose fibers formation and thermal properties (Figure 4).

\subsection{In Vivo Analysis}

Patient enter in Hospital on 12/10/2014 under supervision of Dr. Saqer Al Mualla Consultant Head of Plastic Surgeons Dept' and Dr. Raed Farahat Plastic Surgeon Specialist, the case planed for skin graft after getting good clean granulation tissue. It was performed immediate intervention with antibiotics and clinical protocols for this disease. In 12/15/2014, started treatment with Bacterial cellulose membranes (Nanoskin ${ }^{\circledR}$ ), one membrane of Nanoskin applied to the wound after removal of all air bubbles under dry gauze used as secondary dressing and light pressure bandage over (Figure 5).
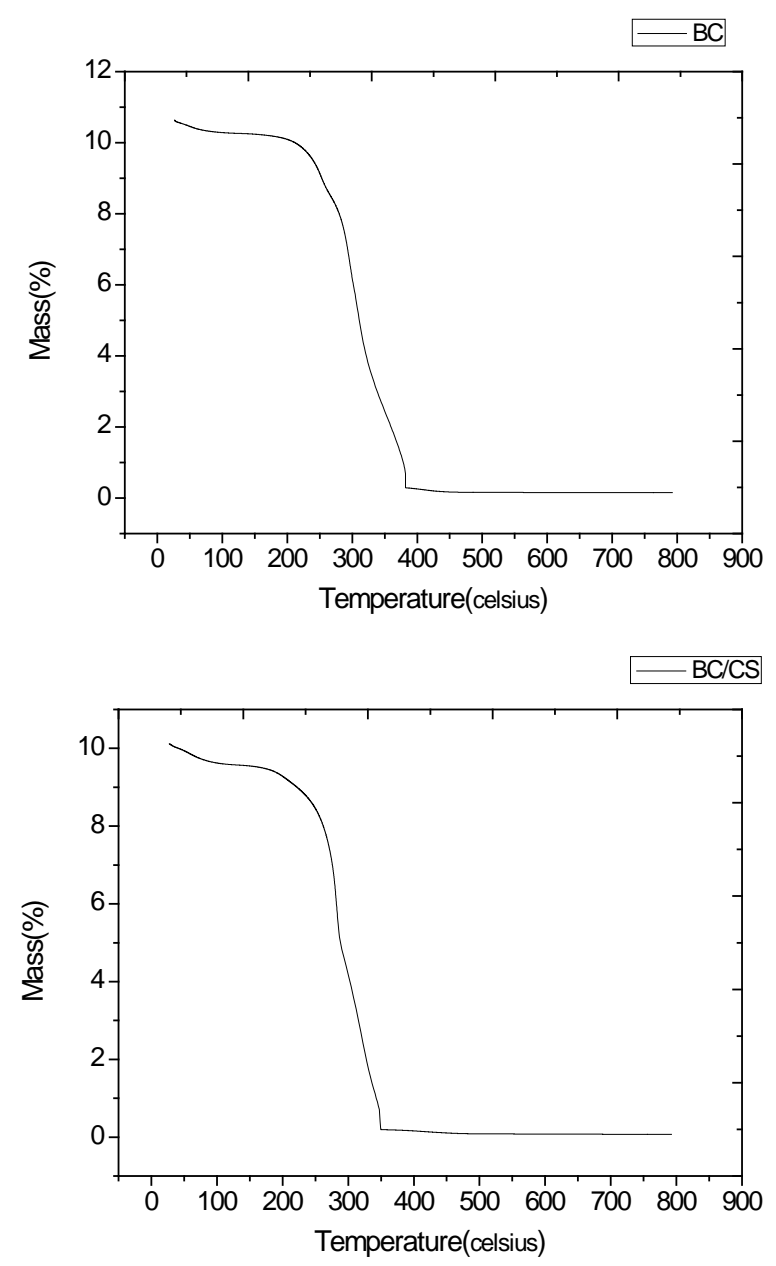

Figure 3. TGA thermogram of bacterial cellulose/chondroitin 4-sulfate nanocomposites samples. 


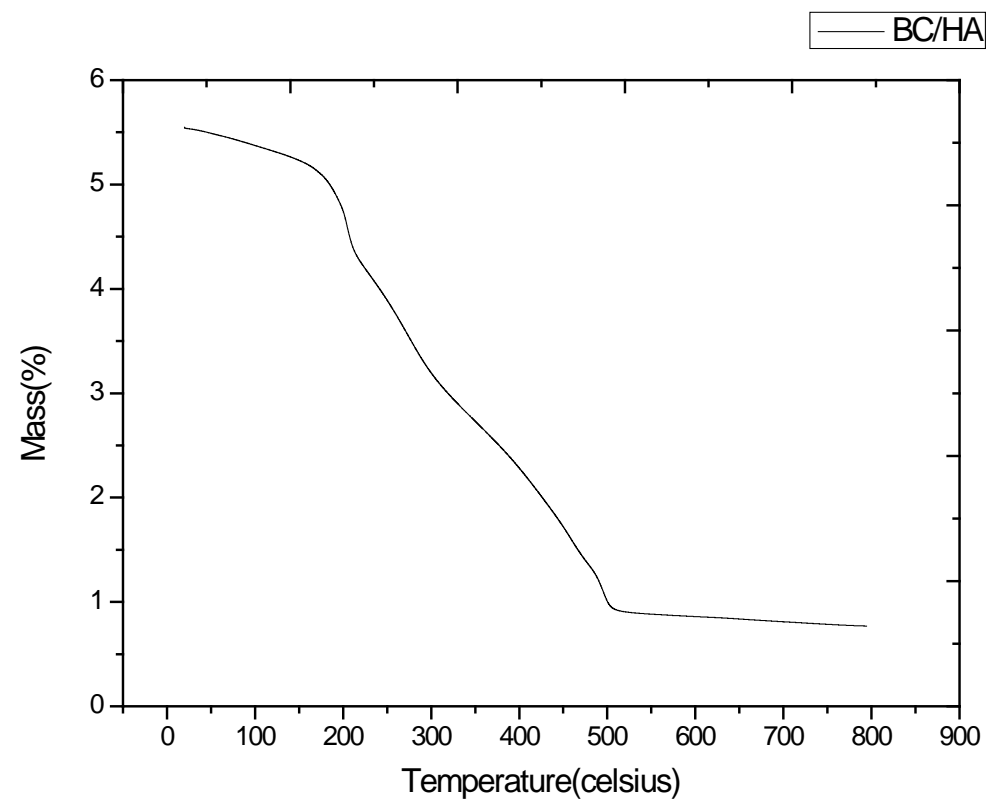

Figure 4. TGA thermogram of bacterial cellulose/hyaluronic acid nanocomposites samples.
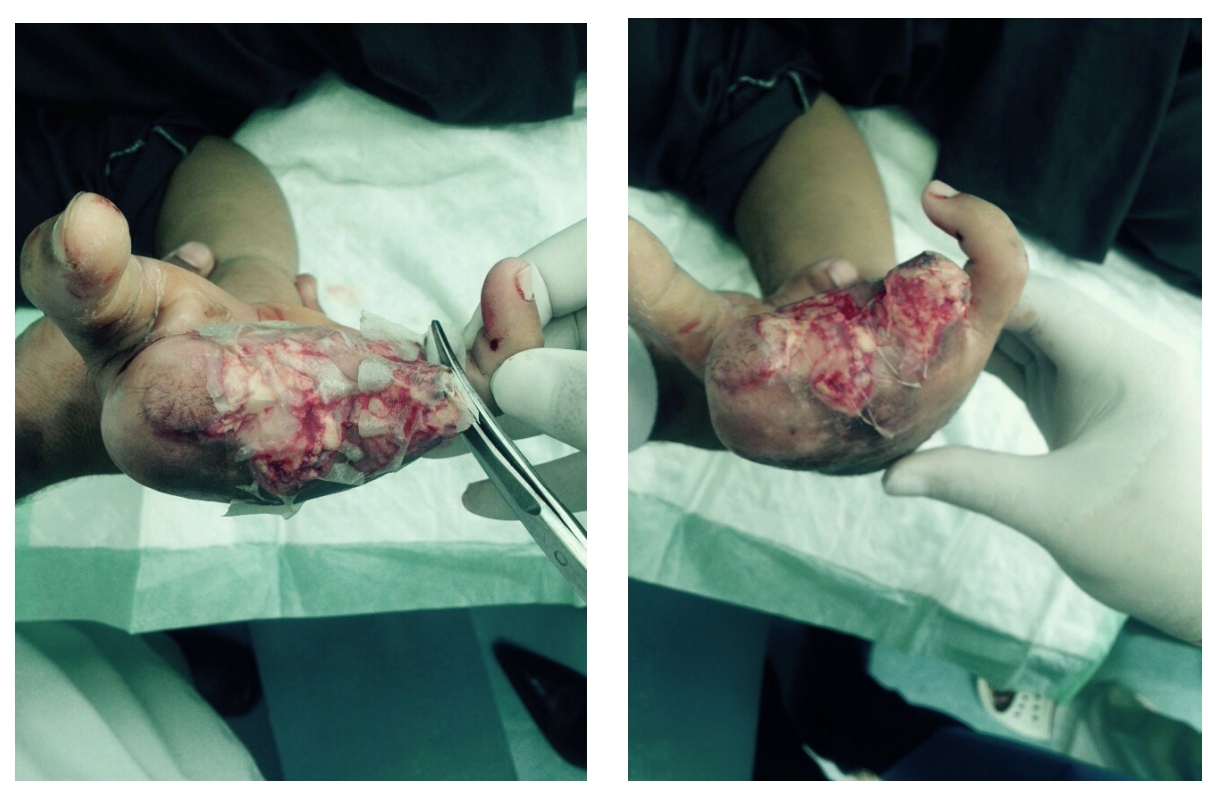

Figure 5. Bacterial cellulose $\left(\right.$ Nanoskin ${ }^{\circledR}$ ) uses like biological wound dressing.

After using the Bacterial cellulose material in alternate days, it can be observed a recovery of the edge and bottom of the wound, however, after $1^{\text {st }}$ week the wound was better and with necrotic, so, debridement was done and applied Nanoskin (Figure 6).

After, in $2^{\text {nd }}$ week, wound getting better with minimal exudate and better wound bed. The edge looks health and normal health margin, healthy granulation tissue and no odor and decrease the size of wound bed (Figure 7).

The simple application of dressing, only required the association of saline, gauze and bandage, decrease patient stay and operating room use, resulting in a better cost-benefit. All wounds gets better with Nanoskin ${ }^{\circledR}$ dressing, dramatic changes was noted after application of Nanoskin ${ }_{-}^{\circledR}$ dressing, patient rarely complain of pain. Healing happened by normal health tissue with less fibrous tissue, normal skin and no pigmentation, besides fast epithelization was observed. The wound healed in 19 days, then the wound coming better even Ring of the hand healed completely after 5 weeks (Figure 8). 

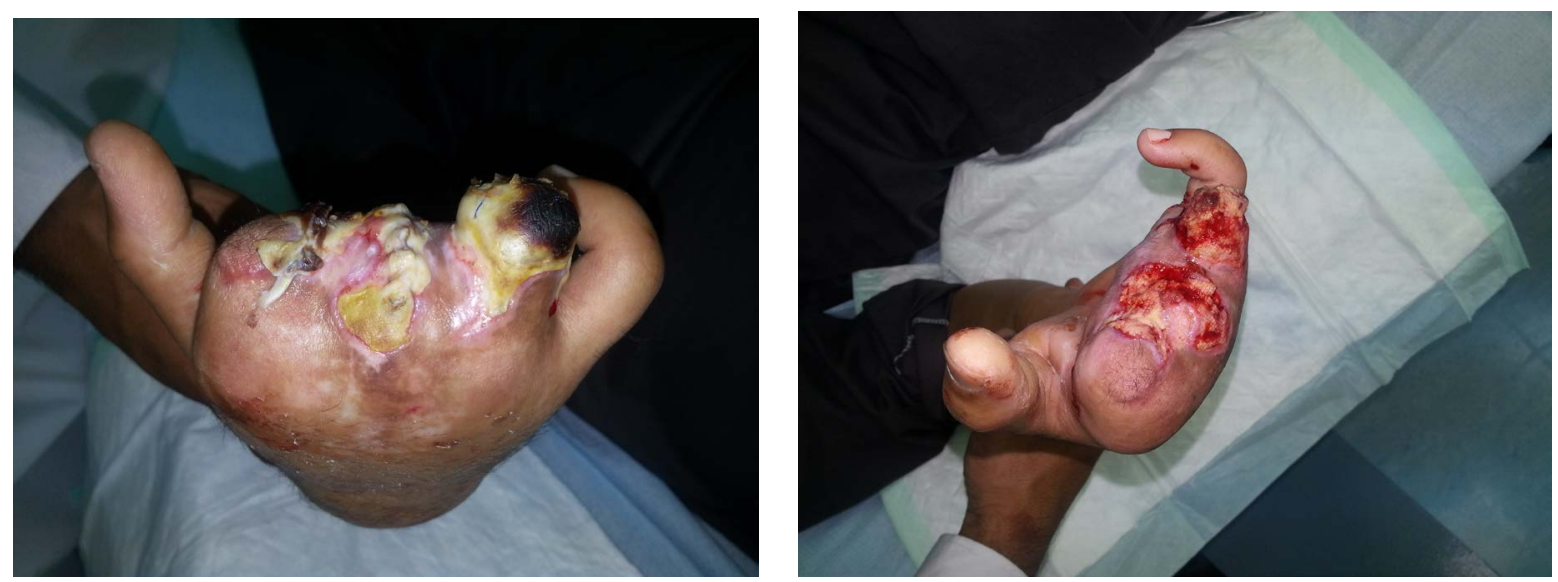

Figure 6. Wound healing evolution in 1weeks with bacterial cellulose (Nanoskin ${ }^{\circledR}$ ).
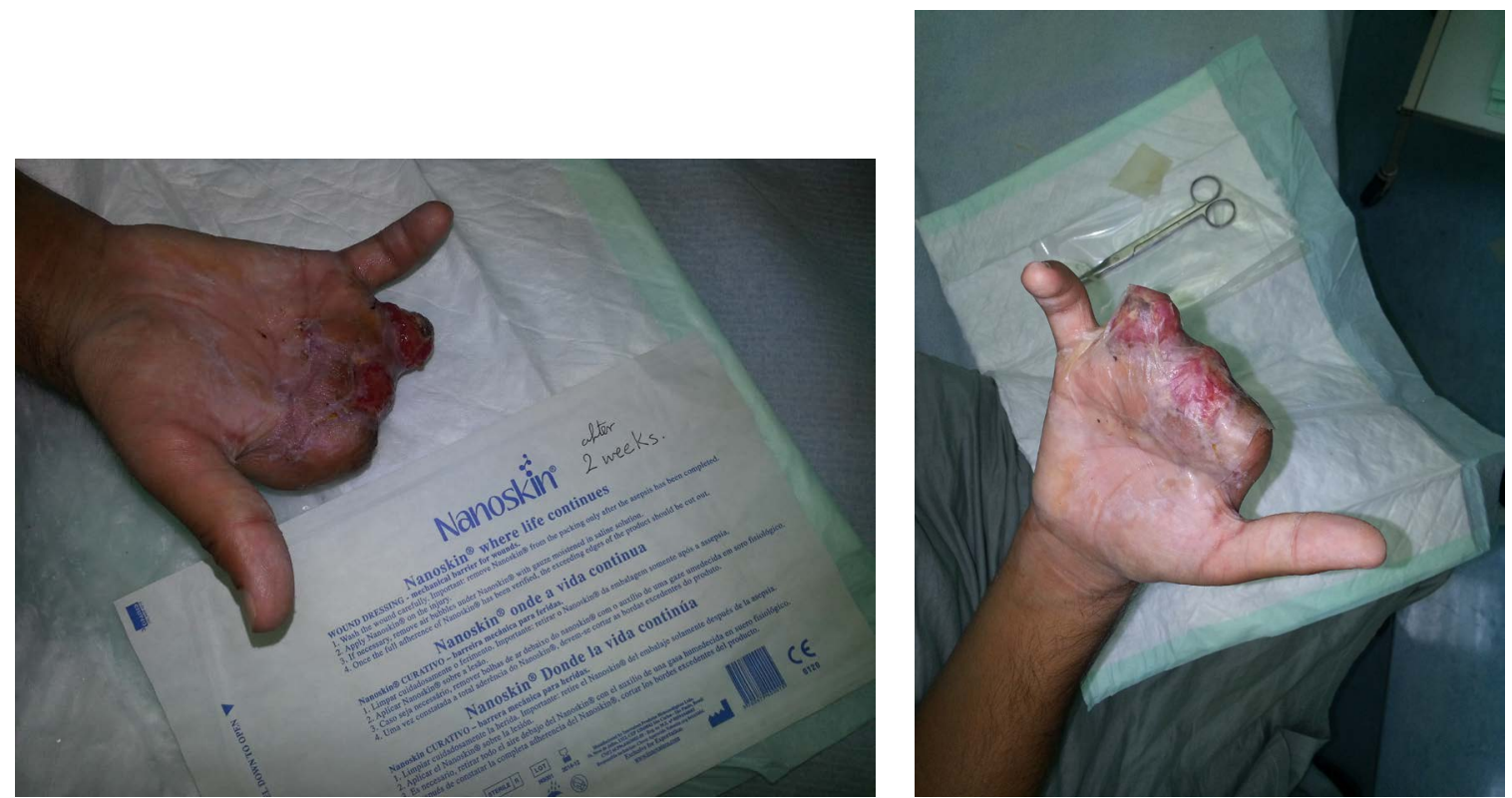

Figure 7. Wound healing evolution in 2 weeks with bacterial cellulose (Nanoskin ${ }^{\circledR}$ ).

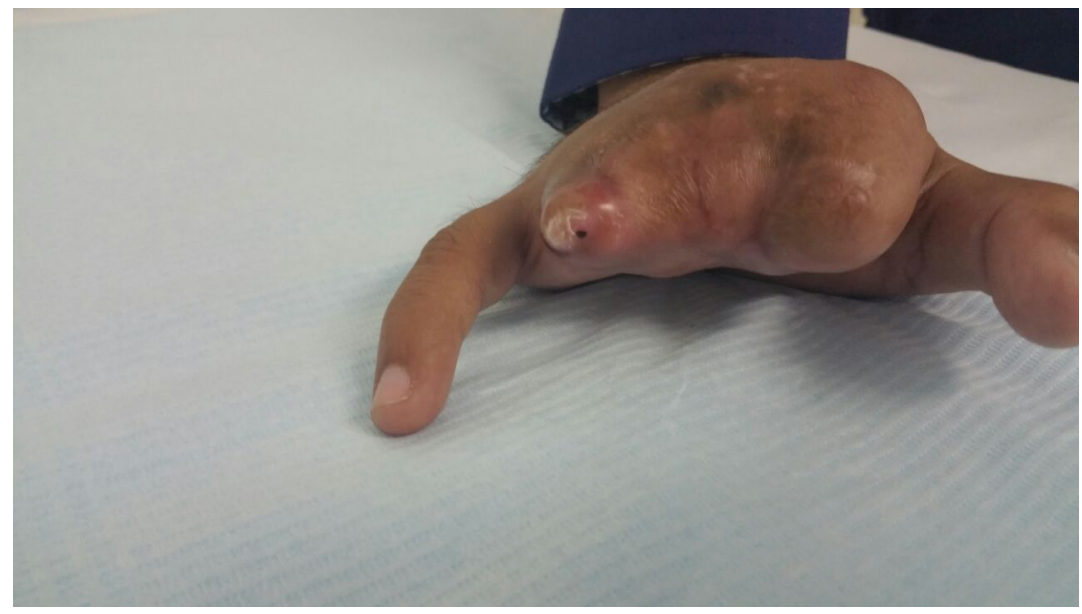

Figure 8. Completed wound healing in 19 days with bacterial cellulose (Nanoskin ${ }^{\circledR}$ ). 


\section{Conclusions}

Bacterial cellulose $\left(\right.$ Nanoskin $^{\circledR}$ ) was successfully modified by changing the fermentation medium as shown by FTIR and TGA, which produced suitable scaffolds for use in surface morphology applications with promising cell viability/attachment. Nanoskin Natural extracellular matrix (ECMs) perform the tasks necessary for tissue formation, maintenance, regulation and function, providing a powerful means of controlling the biological performance of regenerative materials. However, understanding how cells interact with these to assemble their own ECM and how the scaffolds can be used to control delivery of signals in a temporal and spatial manner to guide or maintain cell differentiations need future investigation. But, undoubtedly, natural-origin polymers or natureinspired materials appear as the natural and desired choice for medical applications.

In conclusion, Bacterial cellulose membrane $\left(\right.$ Nanoskin $\left.^{\circledR}\right)$ applies to the protective surface and sutures, in exudate lesions, promoting the healing process with no rejection body, besides decreasing recovery time and the treatment cost.

\section{References}

[1] Thakur, R., Jain, N., Pathak, R. and Sandhu, S.S. (2011) Practices in Wound Healing Studies of Plants. EvidenceBased Complementary and Alternative Medicine, 2011, Article ID: 438056, 1-17. http://dx.doi.org/10.1155/2011/438056

[2] Basmaji, P., de Olyveira, G.M., Manzine Costa, L.M., Francozo, G.B. and da Costa Oliveira, J.D. (2015) Nanoderm Extracellular Matrix for Reconstructive Surgery Applications. Peertechz Journal of Biomedical Engineering, 1, 021024.

[3] Basmaji, P., Ambrizzi, D.R., Olyveira,G.M., Costa,L.M.M., Francozo, G.B., Oliveira, J.D.C.(2016) Natural Extracellular Matrix Modified for Tissue Engineering Applications. Advanced Science, Engineering and Medicine, 8, 62-67. http://dx.doi.org/10.1166/asem.2016.1817

[4] Basmaji, P., Olyveira, G.M., Costa, L.M.M., Souza, J.A.M., Lucchesi, G.L., Amariz, G.A.S., Affonso, M.E.R.M., Amaral, N.C.P., Oliveira, J.D.C. and Francozo, G.B. (2015) Natural ECM-Biological Wound Dressing. Aperito Journal of Nanoscience Technology, 2, 105-110.

[5] Olyveira, G.M., Santos, M.L., Daltro, P.B., Basmaji, P., Daltro, G.C. and Guastaldi, A.C. (2014) Bacterial Cellulose/ Chondroitin Sulfate for Dental Materials Scaffolds. Journal of Biomaterials and Tissue Engineering, 4, 150-154. http://dx.doi.org/10.1166/jbt.2014.1155

[6] Olyveira, GM., Santos, M.L., Costa, L.M.M., Daltro, P.B., Basmaji, P., Daltro, G.C. and Guastaldi, A.C. (2014) Bacterial Cellulose Nanobiocomposites for Dental Materials Scaffolds. Journal of Biomaterials and Tissue Engineering, 4, 536-542. http://dx.doi.org/10.1166/jbt.2014.1202

[7] Olyveira, G.M., Santos, M.L., Costa, L.M.M., Daltro, P.B., Basmaji, P., Daltro, G.C. and Guastaldi, A.C. (2014) Bacterial Biocomposites for Guided Tissue Regeneration. Science of Advanced Materials, 6, 2673-2678. http://dx.doi.org/10.1166/sam.2014.1985

[8] Olyveira, G.M., Santos, M.L., Costa, L.M.M., Daltro, P.B., Basmaji, P., Daltro, G.C. and Guastaldi, A.C. (2015) Physically Modified Bacterial Cellulose Biocomposites for Guided Tissue Regeneration. Science of Advanced Materials, 7, 1657-1664. http://dx.doi.org/10.1166/sam.2015.2283

[9] Olyveira, G.M., Santos, M.L., Costa, L.M.M., Riccardi, C.S., Daltro, P.B., Basmaji, P., Daltro, G.C. and Guastaldi, A.C. (2015) Physically Modified Bacterial Cellulose Biocomposites for Dental Materials Scaffolds. Materials Focus, 4, 111-117. http://dx.doi.org/10.1166/mat.2015.1224

[10] Olyveira, G.M., Acasigua, G.A.X., Costa, L.M.M., Scher, C.R., Filho, L.X., Pranke, P.H.L. and Basmaji, P. (2013) Human Dental Pulp Stem Cell Behavior Using Natural Nanotolith/Bacterial Cellulose Scaffolds for Regenerative Medicine. Journal of Biomedical Nanotechnology, 9, 1370-1377. http://dx.doi.org/10.1166/jbn.2013.1620

[11] Acasigua, G.A.X., Olyveira, G.M., Costa, L.M.M., Braghirolli, D.A., Guastaldi, A.C., Pranke, P. and Basmaji, P. (2014) Novel Natural Bacterial Cellulose Nanocomposites as Potential Biomaterial for Stem Cell Therapy. Current Stem Cell Research \& Therapy, 9, 117-123. http://dx.doi.org/10.2174/1574888X08666131124135654

[12] El-Hoseny, S.M., Basmaji, P., Olyveira, G.M., Costa, L.M.M., Alwahedi, A.M., Oliveira, J.D.C. and Francozo, G.B. (2015) Natural ECM-Bacterial Cellulose Wound Healing-Dubai Study. Journal of Biomaterials and Nanobiotechnology, 6, 237-246. http://dx.doi.org/10.4236/jbnb.2015.64022

[13] Faria, E., Blanes, L., Hochman, B., Filho, M.M. and Ferreira, L. (2011) Health-Related Quality of Life, Self-Esteem, and Functional Status of Patients with Leg Ulcers. Wounds, 23, 4-10.

[14] Siddiqui, A.R. and Bernstein, J.M. (2010) Chronic Wound Infection: Facts and Controversies. Clinics in Dermatology, 
28, 519-526. http://dx.doi.org/10.1016/j.clindermatol.2010.03.009

[15] Han, A., Zenilman, J.M., Melendez, J.H., Shirtliff, M.E., Agostinho, A., James, G., Stewart, P.S., Mongodin, E.F., Rao, D., Rickard, A.H. and Lazarus, G.S. (2011) The Importance of a Multi-Faceted Approach to Characterizing the Microbial Flora of Chronic Wounds. Wound Repair and Regeneration, 19, 532-541. http://dx.doi.org/10.1111/j.1524-475X.2011.00720.x

[16] Costa, L.M.M., Olyveira, G.M., Basmaji, P., Valido, D.P., Góis, P.B.P., Júnior, R.L.A.C. and Filho, L.X. (2012) Novel Otoliths/Bacterial Cellulose Nanocomposites as a Potential Natural Product for Direct Dental Pulp Capping. Journal of Biomaterials and Tissue Engineering, 2, 48-53. http://dx.doi.org/10.1166/jbt.2012.1031

[17] de Olyveira, G.M., Luiz dos Santos, M., dos Santos Riccardi, C., Costa, L.M.M., Daltro, P.B., Basmaji, P., de Cerqueira Daltro, G. and Guastaldi, A.C. (2015) Bacterial Cellulose Biocomposites for Periodontology Treatment. Advanced Science, Engineering and Medicine, 7, 409-414. http://dx.doi.org/10.1166/asem.2015.1641

[18] Costa, L.M.M., Olyveira, G.M., Basmaji, P. and Filho, L.X. (2011) Bacterial Cellulose towards Functional Green Composites Materials. Journal of Bionanoscience, 5, 167-172. http://dx.doi.org/10.1166/jbns.2011.1060

[19] Costa, L.M.M., Olyveira, G.M., Basmaji, P. and Filho, L.X. (2012) Bacterial Cellulose towards Functional Medical Materials. Journal of Biomaterials and Tissue Engineering, 2, 185-196. http://dx.doi.org/10.1166/jbt.2012.1044

[20] Molina de Olyveira, G., Maria Manzine Costa, L. and Basmaji, P. (2013) Physically Modified Bacterial Cellulose as Alternative Routes for Transdermal Drug Delivery. Journal of Biomaterials and Tissue Engineering, 3, 227-232. http://dx.doi.org/10.1166/jbt.2013.1079

[21] Olyveira, G.M., Riccardi, C.S., Santos, M.L., Costa, L.M.M., Daltro, P.B., Basmaji, P., Daltro, G.C. and Guastaldi, A.C. (2014) Bacterial Cellulose Nanobiocomposites for Periodontal Disease. Journal of Bionanoscience, 8, 319-324. http://dx.doi.org/10.1166/jbns.2014.1241

[22] Gois, P.B.P., Olyveira, G.M., Costa, L.M.M., Chianca, C.F., Fraga, I.I.S., Basmaji, P., Cordoba, C.V. and Filho, L.X. (2013) Influence of Symbioses Culture between Microorganisms/Yeast Strain on Cellulose Synthesis. International Review of Biophysical Chemistry, 3, 48-54.

[23] Filho, L.X., OLyveira, G.M., Costa, L.M.M. and Basmaji, P. (2013) Novel Electrospun Nanotholits/PHB Scaffolds for Bone Tissue Regeneration. Journal of Nanoscience and Nanotechnology, 13, 4715-4719. http://dx.doi.org/10.1166/jnn.2013.7191

[24] Olyveira, G.M., Costa, L.M.M., Basmaji, P. and Filho, L.X. (2011) Bacterial Nanocellulose for Medicine Regenerative. Journal of Nanotechnology in Engineering and Medicine, 2, 34001-34009. http://dx.doi.org/10.1115/1.4004181

[25] Salmen, L., Akerholm, M. and Hinterstoisser, B. (2005) Two-Dimensional Fourier Transform Infrared Spectroscopy Applied to Cellulose and Paper. In: Dumitriu, S., Ed., Polysaccharides: Structural Diversity and Functional Versatility, 2nd Edition, Marcel Dekker, New York, 159-187.

[26] Kondo, T. (1998) Hydrogen Bonds in Cellulose and Cellulose Derivatives. In: Dumitriu, S., Ed., Polysaccharides: Structural Diversity and Functional Versatility, Marcel Dekker, New York, 131-172.

[27] Manfredi, L.B., Rodriguez, E.S., Wladyka-Przybylak, M. and Vazquez, A. (2006) Thermal Degradation and Fire Resistance of Unsaturated Polyester Modified Acrylic Resins and Their Composites with Natural Fibers. Polymer Degradation and Stability, 91, 255-261. http://dx.doi.org/10.1016/j.polymdegradstab.2005.05.003

[28] Ouajai, S. and Shanks, R.A. (2006) Solvent and Enzyme Induced Recrystallization of Mechanically Degraded Hemp Cellulose. Cellulose, 13, 31-44. http://dx.doi.org/10.1007/s10570-005-9020-5

[29] Alvarez, V.A., Ruseckaite, R.A. and Vazquez, A. (2006) Degradation of Sisal Fibre/Mater Bi-Y Biocomposites Buried in Soil. Polymer Degradation and Stability, 91, 3156-3162. http://dx.doi.org/10.1016/j.polymdegradstab.2006.07.011

[30] Deepa, B., Abraham, E., Cherian, B.M., Bismarc, A., Blaker, J.J. and Pothan, L.A. (2011) Structure, Morphology and Thermal Characteristics of Banana Nano Fibers Obtained by Steam Explosion. Bioresource Technology, 102, 19881997. http://dx.doi.org/10.1016/j.biortech.2010.09.030 